\title{
Acute effects of summer air pollution on respiratory function in primary school children in southern England
}

\author{
J F Scarlett, K J Abbott, JL Peacock, D P Strachan, H R Anderson
}

\begin{abstract}
Background - There is growing concern about health effects of air pollution in the UK. Studies in the USA have reported adverse effects on lung function among children but no comparable studies have been published in the UK. This study investigates the relationship between daily changes in ambient air pollution and short term variations in lung function in a panel of school children.
\end{abstract}

Methods - One hundred and fifty four children aged 7-11 attending a primary school adjacent to a major motorway in Surrey, south-east England, were studied. Bellows spirometry was performed daily on 31 schooldays between 6 June and 21 July 1994. Levels of ozone, nitrogen dioxide, and particulates of less than $10 \mu \mathrm{m}$ in diameter $\left(\mathbf{P M}_{10}\right)$ were measured continuously at the school and the pollen count was measured six miles away. Relationships between daily changes in forced expiratory volume in 0.75 seconds $\left(F E V_{0.75}\right)$, forced vital capacity (FVC), the $\mathrm{FEV}_{0.75} / \mathrm{FVC}$ ratio and pollutants were analysed using separate autoregressive models for each child. A weighted average of the resulting slopes was then calculated.

Results - There was a significant inverse relationship between daily mean $\mathbf{P M}_{10}$ levels lagged one day and FVC, with a reduction in lung function of $1 \%(95 \%$ CI $0.3 \%$ to $2 \%$ ) across the whole range of $\mathbf{P M}_{10}$ levels $\left(20-150 \mu \mathrm{g} / \mathrm{m}^{3}\right)$. The effect on $\mathrm{FEV}_{0.75}$ was similar $(-0.5 \%)$ but was not significant when weighted by $1 / \mathrm{SE}^{2}(95 \% \mathrm{CI}$ $-1.2 \%$ to $0.2 \%)$. There was no effect of $\mathbf{P M}_{10}$ levels on the $\mathrm{FEV}_{0.75} / \mathrm{FVC}$ ratio. No significant association was seen between $\mathrm{FEV}_{0.75}, \mathrm{FVC}$, or the $\mathrm{FEV}_{0.75} / \mathrm{FVC}$ ratio and either ozone or nitrogen dioxide levels. There was no evidence that wheezy children were more affected than healthy children. Pollen levels on the previous day had no effect on lung function and did not change the air pollution results.

Conclusions - There is a very small, but statistically significant, adverse effect of airborne respirable particulate matter, measured as $\mathbf{P} \mathbf{M}_{10}$, on lung function in this study group. There is no evidence for an inverse association of lung function with levels of ozone or $\mathrm{NO}_{2}$ measured on the previous day.

(Thorax 1996;51:1109-1114)
Keywords: air pollution, particulates, lung function, school children.

There is growing concern about the health effects of air pollution within the range observed in the UK at the present time. ${ }^{1-3}$ Much of the evidence comes from studies of the short term effects of air pollution carried out in the USA where associations have been observed with daily mortality, health service utilisation, and respiratory symptoms in asthma patients, and with a reduction in lung function in both asthmatic and normal subjects. ${ }^{4-6}$ The most consistently reported associations are with particles and ozone. A few recent reports from the UK indicate that levels of air pollution currently encountered may have measurable but small effects on hospital admissions ${ }^{7}$ and on the lung function of adult asthmatic patients. ${ }^{8}$ No UK studies have examined the effects of air pollution on lung function in children.

In south-east England there has been considerable public concern about pollution arising from the motorway (M25) which orbits Greater London. During the summer of 1994 a local authority arranged the monitoring of particulates $\left(\mathrm{PM}_{10}\right)$, oxides of nitrogen, and ozone in outside air in a primary school playground on the upwind border of the motorway. ${ }^{9} \mathrm{We}$ took this opportunity to investigate the relationship between daily changes in ambient levels of nitrogen dioxide, $\mathrm{PM}_{10}$, and ozone at the school and daily changes in the respiratory function of children attending the school.

\section{Methods}

SUBJECTS AND MEASUREMENTS

Classes in which most children were aged eight or over were eligible for inclusion in the study. Parents were sent an explanatory letter, a consent form, and a brief questionnaire about their child's respiratory health based on a standard asthma questionnaire. ${ }^{10}$

Lung function was measured every school day from 6 June to 21 July 1994 using S-model vitalographs (Vitalograph Ltd, Buckingham, UK). Before the study began a training day was held, supervised by a senior respiratory epidemiologist (DPS). The staff who would subsequently supervise the study on a day-today basis were firstly trained to operate the vitalographs and then the children were trained how to blow. Children who were unable to master the technique of blowing (only a very few) were still allowed to participate but their 
spirograms were discarded. Great emphasis was put on each child using maximum effort throughout the entire study period. Each child was supervised for each blow throughout the study.

Other factors which may influence lung function measurements were also recorded daily. These included time of measurement, symptoms of respiratory infection, vitalograph used, and vitalograph operator. Children on medication for asthma were asked whether they had taken any medication that day. Unfortunately, the quality of these data was poor and so they were not used in the analysis. At worst this would bias the regression coefficients towards the null value.

Each vitalograph was calibrated daily using a one litre syringe. Each child performed three forced expiratory manoeuvres to obtain repeatable measures. The highest values of forced expiratory volume in 0.75 seconds $\left(\mathrm{FEV}_{0.75}\right)$ and forced vital capacity (FVC) each day were used in the analysis.

\section{ENVIRONMENTAL MONITORING}

Oxides of nitrogen were monitored continuously by the chemiluminescence technique and were reported as daily mean and maximum one hour means. Ozone was measured using an ultraviolet detector and reported as maximum eight hour and one hour means. $\mathrm{PM}_{10}$ levels were measured by gravimetric analysis of particulates collected on filters and reported as daily means. ${ }^{9}$ Relative humidity and air temperature were also measured at the school. Daily pollen counts were obtained from the local authority monitoring site six miles away.

\section{STATISTICAL ANALYSIS}

The general approach was to analyse the relationship between lung function and ambient air pollution separately for each child and then to pool the results. ${ }^{11}$ Thus, each child acted as his or her own control. The mean lung function measure was calculated for each child and then the difference between this mean and each day's reading was noted. This gave a set of daily deviations from individual means which were adjusted by multiple regression for the following "nuisance" variables: machine ( $\mathrm{n}=$ $5)$, operator $(n=10)$, time of day and day of week (weekends versus weekdays). Time of day had no significant effect on lung function and so was omitted. We also tested for a time trend ("learning" effect) but none was found. For each child the adjusted daily deviations were used as the outcome variable in a multiple regression analysis investigating the effect of each pollutant in turn and allowing for confounding by temperature, humidity, and pollen count. To allow for first order autocorrelation, these analyses used Cochrane-Orcutt regression. ${ }^{12}$ Individual scatterplots of the raw data suggested linearity for most children and so linear terms were used in the regressions. Most children were measured in the morning and so it was appropriate to consider pollutant measures lagged by one and two days. Stronger associations were found with one day lags and so these are reported here.

The individual regression analyses produced a regression coefficient for each child which described the linear relationship between lung function and each air pollutant. The heterogeneity of the slopes was tested using a standard test. ${ }^{13}$ It seemed likely that the precision which could be attached to the slopes would vary between individuals and hence some form of weighted summary measure might be appropriate. The precision of a slope is related to the number of observations on the subject and the fit of the line. It was not obvious which was the most appropriate weight to use and so we computed three summary measures: an unweighted average, an average weighted according to the number of observations, and an average weighted inversely according to the variance of the slope. The method for weighting inversely according to the variance took into account both within and between subject variability. ${ }^{14}$ All statistical analyses were done using STATA. ${ }^{15}$

In summarising the effects of the various pollutants we have used percentage rather than absolute changes in lung function since mean lung function increases with age among children so the clinical importance of absolute changes is not constant. In addition, the use of percentage changes allows comparison with studies in adults.

Ethical approval for the study was obtained from North West Surrey local research ethics committee.

\section{Results}

\section{STUDY SUBJECTS}

One hundred and fifty four children (63 boys) took part in the study. Fourteen had wheezed in the past 12 months, nine of whom were on medication for asthma. A further 14 children had wheezed previously but not in the past 12 months. Lung function measurements were taken on a total of 31 school days; $92 \%$ of children had 25 or more readings.

\section{SUMMARY STATISTICS}

Table 1 shows the summary data for lung function, pollution, and meteorological measurements for the period of the study (including weekends) and fig 1 shows the time series of the three monitored pollutants. There were several occasions during June and July when pollution levels were above current guideline levels. On one day $\mathrm{PM}_{10}$ levels equalled the US Environmental Protection Agency guideline of an average of $150 \mu \mathrm{g} / \mathrm{m}^{3}$ for 24 hours. The recently published standard for the UK of $50 \mu \mathrm{g} / \mathrm{m}^{3}$ (24 hour running mean) ${ }^{16}$ was exceeded on 26 of the 42 days recorded. The eight hour level of ozone exceeded the UK standard of $50 \mathrm{ppb}^{17}$ on 12 of the 47 days, averaging $50.7 \mathrm{ppb}$ per day. The highest one hour $\mathrm{NO}_{2}$ level was $82 \mathrm{ppb}$, well below the WHO guideline of $210 \mathrm{ppb}$.

There was a positive correlation between $\mathrm{NO}_{2}$ and ozone levels but little association 
Table 1 Summary statistics for lung function, pollutants and meteorological measures

\begin{tabular}{|c|c|c|c|c|c|}
\hline Variable & No. & Mean & $S D$ & Min & $\operatorname{Max}$ \\
\hline $\begin{array}{l}\mathrm{FEV}_{0.75}(\text { litres) } \\
\text { FVC (litres) } \\
\text { FEV/FVC } \\
\text { Daily mean } \mathrm{PM}_{10}\left(\mu \mathrm{g} / \mathrm{m}^{3}\right) \\
\text { Max 8-hour average } \mathrm{O}_{3}(\mathrm{ppb})^{*} \\
\text { Max hourly } \mathrm{O}_{3}(\mathrm{ppb}) \\
\text { Max hourly } \mathrm{NO}_{2} \\
\text { Average hourly } \mathrm{NO}_{2} \\
\text { Average hourly temp }\left({ }^{\circ} \mathrm{C}\right) \\
\text { Average hourly } \mathrm{RH}(\%) \\
\left.\text { Pollen (grains } / \mathrm{m}^{3}\right)\end{array}$ & $\begin{array}{r}154 \\
154 \\
154 \\
42 \\
47 \\
47 \\
47 \\
47 \\
47 \\
47 \\
47\end{array}$ & $\begin{array}{l}1.78 \\
2.12 \\
0.84 \\
71.0 \\
50.7 \\
59.8 \\
34.9 \\
16.8 \\
20.8 \\
39.7 \\
68.2\end{array}$ & $\begin{array}{l}0.37 \\
0.44 \\
0.066 \\
30.59 \\
24.48 \\
28.92 \\
19.37 \\
11.42 \\
2.91 \\
10.30 \\
44.50\end{array}$ & $\begin{array}{c}20 \\
6.8 \\
12 \\
6 \\
2.3 \\
14.7 \\
24.8 \\
2\end{array}$ & $\begin{array}{c}150 \\
128 \\
159 \\
82 \\
52.2 \\
28 \\
71.0 \\
183\end{array}$ \\
\hline
\end{tabular}

$\mathrm{FEV}_{0.75}=$ forced expiratory volume in 0.75 seconds; $\mathrm{FVC}=$ forced vital capacity; $\mathrm{PM}_{10}=$ particles of less than $10 \mu \mathrm{m}$ diameter; $\mathrm{O}_{3}=$ ozone; $\mathrm{NO}_{2}=$ nitrogen dioxide; $\mathrm{RH}=$ relative humidity.

$\mathrm{PM}_{10}$ measurements were unavailable for five days.

*Maximum daily eight hour running average.
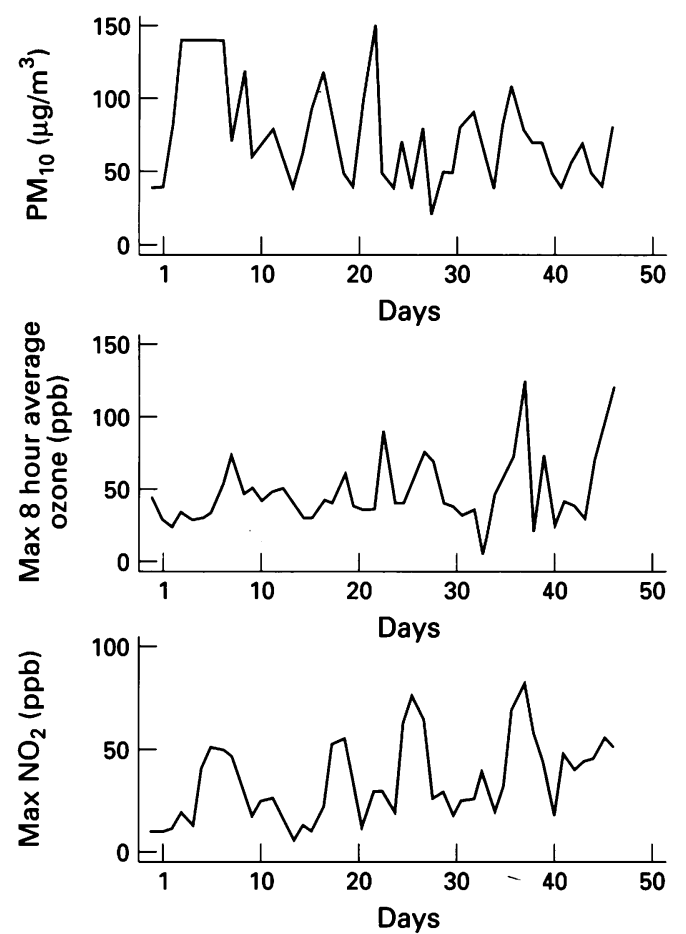

Figure 1 Variation in pollutant levels 5 fune to 21 fuly 1994.

between $\mathrm{PM}_{10}$ levels and either $\mathrm{NO}_{2}$ or ozone (table 2). A small positive correlation was observed between the pollen count and each pollutant but these associations were not statistically significant.

\section{REGRESSION ANALYSES}

Figure 2 shows the distribution of individual regression coefficients (unweighted) for FVC by pollutant. For the ozone and $\mathrm{NO}_{2}$ measures there is a symmetrical scatter around zero, suggesting no overall adverse effect. For $\mathrm{PM}_{10}$ there is a longer tail to the left with a greater proportion of the sample having negative rather than positive slopes. The visual impression of a wide scatter of slopes was confirmed by the tests for heterogeneity which were all statistically significant.

The summary slopes for the indices of lung function are shown in table 3. The slope for the regression of FVC on $\mathrm{PM}_{10}$ levels was negative for each of the three methods of weighting, with $95 \%$ confidence intervals which excluded zero. Using $1 / \mathrm{SE}^{2}$ as the weight, the regression coefficient $-0.17 \times 10^{-3}$ litres $/ \mu \mathrm{g} /$ $\mathrm{m}^{3}$ is equivalent to a reduction in FVC of $1 \%$ (95\% CI $0.3 \%$ to $2 \%$ ) across the range of $\mathrm{PM}_{10}$ levels observed in this study $\left(20-150 \mu \mathrm{g} / \mathrm{m}^{3}\right)$. These effects were not altered when the other pollutants were included in the model (data not shown). Eight-hourly average ozone levels were associated with a non-significant increase of $0.4 \%$ in FVC $(95 \% \mathrm{CI}-0.5 \%$ to $1.3 \%)$ across the study range (6.8-128 ppb). Maximum hourly $\mathrm{NO}_{2}$ levels were associated with an increase of $0.8 \%$ in FVC $(95 \% \mathrm{CI}-0.006 \%$ to $1.6 \%$ ) across the range (6-82 ppb). The results for maximum hourly ozone levels were similar to those for the maximum eight hour average level $(0.6 \%$ increase, $95 \% \mathrm{CI}-0.12 \%$ to $1.4 \%$ ), and the FVC at the average hourly $\mathrm{NO}_{2}$ level was similar to that at the maximum hourly level of $\mathrm{NO}_{2}(0.6 \%$ increase, $95 \% \mathrm{CI}$ $-0.8 \%$ to $1.9 \%$ ).

The relationships between pollutants and $\mathrm{FEV}_{0.75}$ were similar but less consistent across the three summaries than those described above for FVC. The equivalent effect as a percentage across the range of $\mathrm{PM}_{10}$ values observed was $0.5 \%(95 \% \mathrm{CI}-1.2$ to $0.2 \%)$. The $\mathrm{FEV}_{0.75} /$ FVC ratio showed no significant associations with any of the pollutants observed.

Pollen count alone showed no significant effect on $\mathrm{FEV}_{0.75}, \mathrm{FVC}$, or the $\mathrm{FEV}_{0.75} / \mathrm{FVC}$ ratio.

Table 2 Correlation matrix for pollutants and pollen ( $p$ values in parentheses)

\begin{tabular}{|c|c|c|c|c|c|c|}
\hline & $P M_{10}$ & $\begin{array}{l}\text { Max 8-hourly } \\
\text { average } O_{3}\end{array}$ & Max hourly $\mathrm{O}_{3}$ & Max hourly $\mathrm{NO}_{2}$ & Average hourly $\mathrm{NO}_{2}$ & Pollen \\
\hline $\begin{array}{l}\mathrm{PM}_{10} \\
\mathrm{Max} \text { 8-hourly average } \mathrm{O}_{3}\end{array}$ & $\begin{array}{l}1.0 \\
-0.06\end{array}$ & 1.0 & & & & \\
\hline Max hourly $\mathrm{O}_{3}$ & $\begin{array}{l}-0.09 \\
(0.6)\end{array}$ & $\begin{array}{l}0.98 \\
(0.0000)\end{array}$ & 1.0 & & & \\
\hline Max hourly $\mathrm{NO}_{2}$ & $\begin{array}{l}0.07 \\
(0.7)\end{array}$ & $\begin{array}{l}0.50 \\
(0.0003)\end{array}$ & $\begin{array}{l}0.55 \\
(0.0000)\end{array}$ & 1.0 & & \\
\hline Average hourly $\mathrm{NO}_{2}$ & $\begin{array}{l}-0.038 \\
(0.8)\end{array}$ & $\begin{array}{l}0.28 \\
(0.05)\end{array}$ & $\begin{array}{l}0.35 \\
(0.015)\end{array}$ & $\begin{array}{l}0.89 \\
(0.0000)\end{array}$ & 1.0 & \\
\hline Pollen & $\begin{array}{c}0.14 \\
(0.4)\end{array}$ & $\begin{array}{l}0.17 \\
(0.2)\end{array}$ & $\begin{array}{l}0.17 \\
(0.3)\end{array}$ & $\begin{array}{l}0.14 \\
(0.3)\end{array}$ & $\begin{array}{c}0.11 \\
(0.5)\end{array}$ & 1.0 \\
\hline
\end{tabular}


Table 3 Summary regression coefficients for the associations between air pollution and lung function in 154 children

\begin{tabular}{|c|c|c|c|c|c|c|}
\hline \multirow[t]{2}{*}{ Pollutant } & \multicolumn{2}{|c|}{$\begin{array}{l}F E V_{0.75)} \\
\text { (litres } \times 10^{3} / \text { units) }\end{array}$} & \multicolumn{2}{|c|}{$\begin{array}{l}F V C \\
\text { (litres } \times 10^{3} / \text { units) }\end{array}$} & \multicolumn{2}{|c|}{$\begin{array}{l}F E V_{0.75} / F V C \\
\text { (\%/units) }\end{array}$} \\
\hline & Mean slope & $95 \% C I$ & Mean slope & $95 \% C I$ & Mean slope & $95 \% C I$ \\
\hline $\begin{array}{l}\text { Daily mean } \mathrm{PM}_{10}\left(\mu \mathrm{g} / \mathrm{m}^{3}\right) \\
\text { Unweighted } \\
\text { Weighted by number of obs } \\
\text { Weighted by } 1 / \mathrm{SE}^{2}\end{array}$ & $\begin{array}{l}-0.14 \\
-0.13 \\
-0.067\end{array}$ & $\begin{array}{l}-0.25 \text { to }-0.026^{* *} \\
-0.24 \text { to }-0.018^{*} \\
-0.16 \text { to } 0.022\end{array}$ & $\begin{array}{l}-0.14 \\
-0.13 \\
-0.17\end{array}$ & $\begin{array}{l}-0.27 \text { to }-0.016^{*} \\
-0.26 \text { to }-0.0078^{*} \\
-0.27 \text { to }-0.053^{* *}\end{array}$ & $\begin{array}{l}-0.71 \\
-0.36 \\
2.6\end{array}$ & $\begin{array}{l}-5.4 \text { to } 3.9 \\
-4.9 \text { to } 4.2 \\
-0.95 \text { to } 6.2\end{array}$ \\
\hline $\begin{array}{l}\text { Max } 8 \text {-hour average ozone (ppb) } \\
\text { Unweighted } \\
\text { Weighted by number of obs } \\
\text { Weighted by } 1 / \mathrm{SE}^{2}\end{array}$ & $\begin{array}{l}-0.033 \\
-0.026 \\
0.0057\end{array}$ & $\begin{array}{l}-0.20 \text { to } 0.13 \\
-0.19 \text { to } 0.13 \\
-0.12 \text { to } 0.13\end{array}$ & $\begin{array}{l}0.043 \\
0.041 \\
0.069\end{array}$ & $\begin{array}{l}-0.15 \text { to } 0.24 \\
-0.15 \text { to } 0.23 \\
-0.089 \text { to } 0.23\end{array}$ & $\begin{array}{l}-1.8 \\
-1.5 \\
-0.13\end{array}$ & $\begin{array}{l}-8.5 \text { to } 5.0 \\
-8.0 \text { to } 5.0 \\
-5.1 \text { to } 4.8\end{array}$ \\
\hline $\begin{array}{l}\text { Maximum hourly ozone (ppb) } \\
\text { Unweighted } \\
\text { Weighted by number of obs } \\
\text { Weighted by } 1 / \mathrm{SE}^{2}\end{array}$ & $\begin{array}{l}0.0016 \\
0.073 \\
0.018\end{array}$ & $\begin{array}{l}-0.14 \text { to } 0.14 \\
-0.13 \text { to } 0.14 \\
-0.089 \text { to } 0.13\end{array}$ & $\begin{array}{l}0.12 \\
0.12 \\
0.11\end{array}$ & $\begin{array}{l}-0.042 \text { to } 0.29 \\
-0.045 \text { to } 0.28 \\
-0.022 \text { to } 0.25\end{array}$ & $\begin{array}{l}-4.0 \\
-3.6 \\
-2.0\end{array}$ & $\begin{array}{l}-10.0 \text { to } 1.9 \\
-9.3 \text { to } 2.1 \\
-6.3 \text { to } 2.4\end{array}$ \\
\hline $\begin{array}{l}\text { Maximum hourly } \mathrm{NO}_{2}(\mathrm{ppb}) \\
\text { Unweighted } \\
\text { Weighted by number of obs } \\
\text { Weighted by } 1 / \mathrm{SE}^{2}\end{array}$ & $\begin{array}{l}-0.0072 \\
0.10 \\
0.059\end{array}$ & $\begin{array}{l}-0.22 \text { to } 0.20 \\
-0.20 \text { to } 0.22 \\
-0.12 \text { to } 0.24\end{array}$ & $\begin{array}{l}0.19 \\
0.18 \\
0.22\end{array}$ & $\begin{array}{l}-0.085 \text { to } 0.46 \\
-0.093 \text { to } 0.45 \\
-0.0018 \text { to } 0.44\end{array}$ & $\begin{array}{l}-8.4 \\
-7.4 \\
-5.2\end{array}$ & $\begin{array}{l}-1.8 \text { to } 0.84 \\
-17.0 \text { to } 1.8 \\
-1.3 \text { to } 2.1\end{array}$ \\
\hline $\begin{array}{l}\text { Average hourly } \mathrm{NO}_{2}(\mathrm{ppb}) \\
\text { Unweighted } \\
\text { Weighted by number of obs } \\
\text { Weighted by } 1 / \mathrm{SE}^{2}\end{array}$ & $\begin{array}{l}0.056 \\
0.070 \\
-0.00050\end{array}$ & $\begin{array}{l}-0.30 \text { to } 0.41 \\
-0.28 \text { to } 0.42 \\
-0.30 \text { to } 0.30\end{array}$ & $\begin{array}{l}0.27 \\
0.23 \\
0.16\end{array}$ & $\begin{array}{l}-0.19 \text { to } 0.73 \\
-0.22 \text { to } 0.69 \\
-0.23 \text { to } 0.54\end{array}$ & $\begin{array}{r}-13.0 \\
-11.0 \\
-9.9\end{array}$ & $\begin{array}{l}-30.0 \text { to } 3.6 \\
-27.0 \text { to } 5.4 \\
-23.0 \text { to } 3.3\end{array}$ \\
\hline $\begin{array}{l}\text { Pollen count (grains } / \mathrm{m}^{3} \text { ) } \\
\text { Unweighted } \\
\text { Weighted by number of obs } \\
\text { Weighted by } 1 / \mathrm{SE}^{2}\end{array}$ & $\begin{array}{l}0.026 \\
0.028 \\
0.021\end{array}$ & $\begin{array}{l}-0.068 \text { to } 0.12 \\
-0.065 \text { to } 0.12 \\
-0.051 \text { to } 0.092\end{array}$ & $\begin{array}{r}-0.18 \\
-0.011 \\
0.011\end{array}$ & $\begin{array}{l}-0.12 \text { to } 0.087 \\
-0.12 \text { to } 0.093 \\
-0.076 \text { to } 0.099\end{array}$ & $\begin{array}{l}0.00 \\
0.00 \\
0.00\end{array}$ & $\begin{array}{l}-0.0003 \text { to } 0.0003 \\
-0.0003 \text { to } 0.0003 \\
-0.0002 \text { to } 0.0002\end{array}$ \\
\hline
\end{tabular}

${ }^{*} \mathrm{p}<0.05 ;{ }^{* *} \mathrm{p}<0.01$.
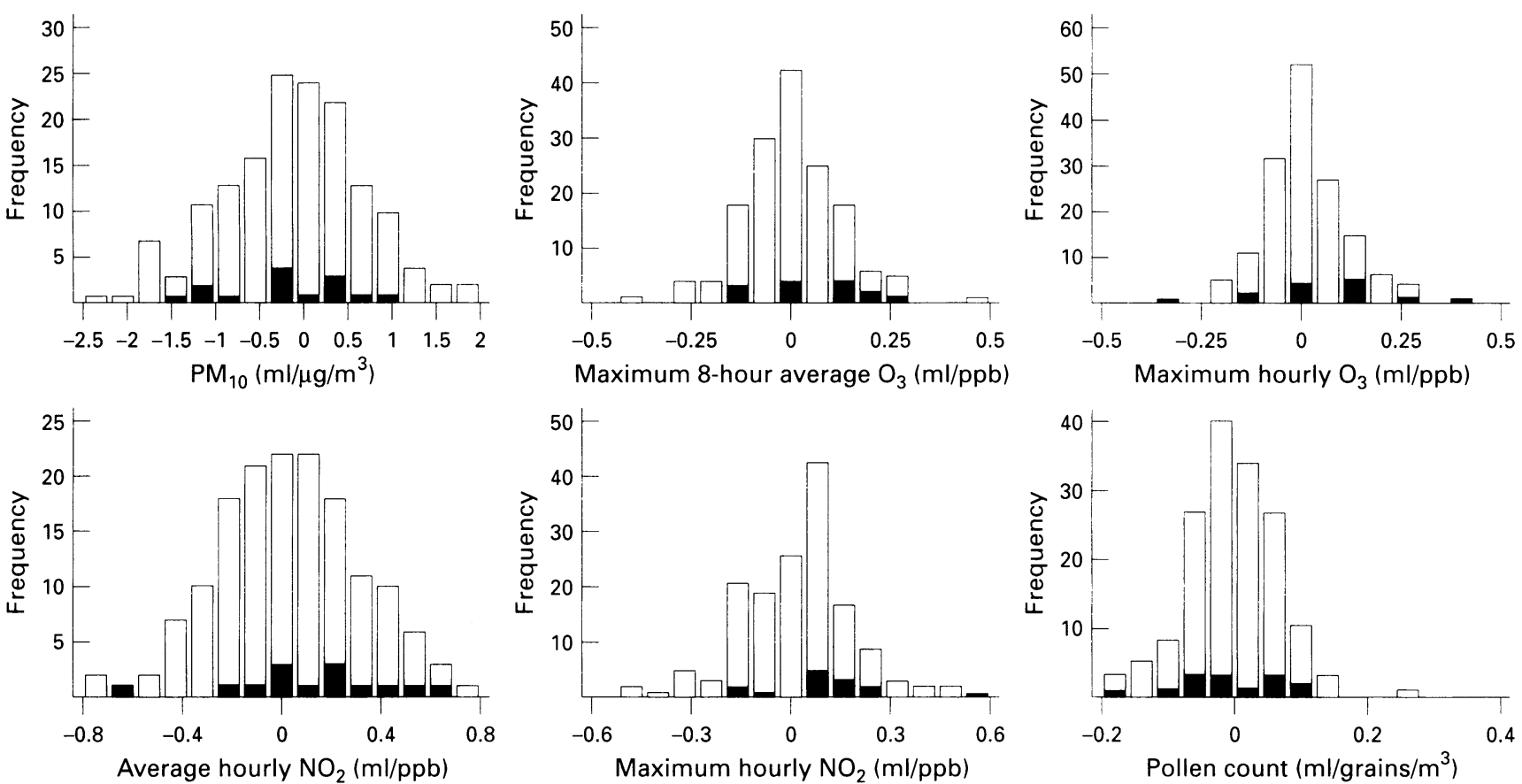

Figure 2 Distributions of slopes (adjusted for nuisance variables and temperature, humidity, pollen, and infection) for regressions of forced vital capacity on pollutants (lagged by one day) and on pollen (single variable model) in 154 children. $\square$, all children; $\square$, current wheezers.

The regression coefficients for the 14 current wheezers (fig 2, black shading) were equally distributed about the centre of the histogram for each pollutant, suggesting no excess risk in this group.

\section{Discussion}

This study suggests that, in healthy children, airborne particles (measured as $\mathrm{PM}_{10}$ ) found in summer pollution in the south of England are associated with a small reduction in ventilatory capacity. The two measured gaseous pollutants, ozone and $\mathrm{NO}_{2}$, were associated with a nonsignificant increase in lung function and the
95\% confidence intervals excluded anything but the smallest decrement. None of the observed effects could be explained by pollen count.

This is the first study of its type to be conducted in the UK. It was relatively large in terms of sample size and number of days of observation and had sufficient power to detect very small effects (of under $1 \%$ change in mean FEV). It is not possible to be entirely certain whether the associations were causal, but great care was taken to control for potential sources of confounding such as temperature and time trends. The number of wheezy children (14/ 154) was sufficient to detect a difference (with 
$90 \%$ power) of four percentage points in mean FVC between wheezers and non-wheezers over the range of $\mathrm{PM}_{10}$ values observed.

Exposure to air pollutants was assessed by a monitor at the school itself. Since most children lived nearby in the town of Egham, the estimate is likely to be applicable to out of school exposure also. However, the actual dose to the lung would also have been affected by indoor levels of these and other pollutants and the level of exercise. Some children lived on the other side (downwind) of the motorway where levels of pollutants were about $30 \%$ higher on average. ${ }^{9}$

In this study we have adopted the estimation approach for presenting results rather than relying on $\mathrm{p}$ values since estimates and confidence intervals are generally accepted as being more informative than $\mathrm{p}$ values alone. Because of the highly correlated nature of the different outcomes and predictor variables considered, particularly when different lags were included, any attempt to quote $p$ values corrected by the Bonferroni method would have very little power. What we have concluded is that there is evidence for a very small adverse effect of $\mathrm{PM}_{10}$, and we rest this on the general consistency of the $\mathrm{PM}_{10}$ results.

Deciding which is the "best" summary measure is not straightforward. The weighting $(=1)$ for the simple average is independent of the data and has some appeal. The number of observations is an intuitive choice since this is independent of the data values. Using the inverse of the variance of the slopes achieves a summary which is not unduly affected by a few very variable individuals. The converse of this is that this method would downweight individuals where the summary is a poor fit to the data, a consequence which would cause some concern. In this data set we checked those individuals with low weights to see if there was any evidence of a relation with the magnitude of the slope. No evidence was found and so we conclude that the summary based on weighting inversely by the variance is the most robust method.

The finding of a significant effect of $\mathbf{P M}_{10}$ levels on lung function is consistent with a number of studies from elsewhere, although the size of the effect is less. A recent review based mainly on American studies ${ }^{6}$ concluded that an increase of $10 \mu \mathrm{g} / \mathrm{m}^{3}$ in $\mathrm{PM}_{10}$ levels is associated with a mean reduction of up to $0.35 \%$ in FEV. This is considerably more than the equivalent decrement of $0.09 \%$ in FEV estimated from the present study. The levels of $\mathrm{PM}_{10}$ observed during our study reached the US EPAQS of $150 \mu \mathrm{g} / \mathrm{m}^{3}$ daily mean and frequently exceeded the recently published UK standard of $50 \mu \mathrm{g} / \mathrm{m}^{3}$ for 24 hours. They were well within the range considered by an expert WHO group to be associated with significant health effects on lung function, daily mortality and hospital admissions, and symptom exacerbations in asthmatic subjects. ${ }^{18}$ Little is known about the composition of $\mathrm{PM}_{10}$ in the UK. ${ }^{19}$ Some is undoubtedly carbonaceous material and, in Surrey, most of this is likely to have come from vehicle (especially diesel) emissions. Chemical components could in- clude sulphates, nitrates or acid aerosols. Irrespective of the composition, the main source of pollution is vehicle emissions.

The ventilatory defect was of a restrictive type, suggesting that $\mathrm{PM}_{10}$ is associated with a stiffening of the lung rather than with airway narrowing. However, it should be noted that the FEV test, while specific for an increase in airways resistance in the larger airways, is not sensitive to changes in smaller airways. The findings are consistent with the theory, supported by evidence from animal studies, that particles, especially fine ones, may cause inflammation of the parenchyma of the lung. ${ }^{3}$ This mechanism may explain the association between particles and clinically significant events such as daily hospital admissions and mortality.

Levels of ozone were within the range associated with reductions in lung function in panel studies in North America and the Netherlands, ${ }^{2021}$ and with evidence of lung inflammation and functional changes in chamber studies. $^{2223}$ The lack of an association in our study is unlikely to be due to low statistical power. In studies in America the effect of ambient ozone levels tends to be greater than that observed in chamber studies, which suggests that other pollutants which co-vary with ozone may also be important. Perhaps the absence of an ozone effect in our study indicates that the pollution mix of which ozone is an indicator is different. An alternative explanation may be that the level of exercise of our primary school children was less than that in the American "summer camp" studies, resulting in a lower dose to the lung.

Levels of $\mathrm{NO}_{2}$ were well within health guideline levels and lower than have been found in chamber studies to be associated with measurable short term health effects. ${ }^{24}$ There are no reports of the effects of $\mathrm{NO}_{2}$ on children's lung function at these levels and our study confirms this. $\mathrm{NO}_{2}$ may have other effects, however, including an effect on the duration of respiratory illnesses in children, ${ }^{25}$ and has been found in a geographical ecological study to be associated with an increase in hospital admissions for all respiratory admissions in children in the West Midlands. ${ }^{26}$

What are the public health implications of these results? A small reduction in lung function due to air pollution is very unlikely to cause lower respiratory symptoms in healthy individuals or even in asthmatic subjects. ${ }^{27}$ However, even a small shift in the distribution of lung function in the population is likely to have a disproportionate effect on the extreme end of the distribution where symptomatic individuals with lung disease are situated. Bearing in mind that there is considerable individual variation in the effects of pollution on the lung, it is plausible that the small mean effects observed in this study could be associated with short term effects on morbidity and even mortality - as has been reported elsewhere.

We are very grateful for the help and support received from the following people and organisations: Mr George Burnett, Surrey County Council; Ms Maureen Chambers, Runnymede Borough Council; Dr Linda Durman, Mid Surrey Health Authority; Mr 
Brian Gabb, Runnymede Borough Council; Dr Mark Goldstone consultants in Environmental Sciences Ltd, and Miss Rachelle Peacock.

The pollution monitoring was funded by Runnymede BorThe pollution monitoring was funded by Runnymede Borough Council and the data collection was funded by Mid Surrey by Surrey County Council.

1 Department of Health. Advisory Group on the Medical Aspects of Air Pollution Episodes. First report: Ozone. London: HMSO, 1991 .

2 Department of Health Advisory Group on the Medical Aspects of Air Pollution Episodes. Fifth report: Health effects of exposures to mixtures of pollutants. London: HMSO, 1995.

3 Department of Health Committee on the Medical Effects of Air Pollutants. Non-biological particles and health. London: HMSO, 1995.

4 Dockery DW, Pope CA. Acute respiratory effects of particulate air pollution. Ann Rev Public Health 1994;15: $107-32$.

5 Schwartz J. Air pollution and daily mortality: a review and meta analysis. Environ Res 1994;64:36-52.

6 Pope CA, Dockery DW, Schwartz J. Review of epidemiological evidence of health effects of particulate pollution. Inhalat Toxicol 1995;7:1-18.

7 Walters S, Griffiths RK, Ayres J. Temporal association between hospital admissions for asthma in Birmingham and ambient levels of sulphur dioxide and smoke. Thorax 1994; 49:133-40.

8 Higgins BG, Francis HC, Yates CJ, Warburton CJ, Fletcher AM, Reid JA, et al. Effects of air pollution on symptoms and peak expiratory flow measurements in subjects with obstructive lung disease. Thorax 1995;50:149-55.

9 Consultants in Environmental Sciences Ltd. Ambient air quality survey - M25. Runnymede: Runnymede Borough Council, 1994

10 Pearce N, Weiland S, Keil U, Langridge P, Anderson HR, Strachan D, et al. Self-reported prevalence of asthma symptoms in children in Australia, England, Germany and New Zealand: an international comparison using the ISAAC protocol. Eur Respir F 1993;6:1455-61.

11 Whittemore AS. Asthma and air pollution in the Los Angeles area. Am 7 Public Health 1980;70:687-97.

12 Cochrane D, Orcutt GH. Application of least-squares regression to relationships containing auto correlated error terms. F Am Stat Assoc 1949;44:32-61.
13 Armitage P, Berry G. Statistical methods in medical research. 3rd edn. Oxford: Blackwell, 1994: chapter 9.

14 Matthews JNS. A refinement to the anaysis of serial data using sum

Corporation. Stata statistical software: release 4.0. College Station Texas: Stata Corporation, 1995.

16 Expert Panel on Air Quality Standards. Particles. London: HMSO, 1995.

17 Expert Panel on Air Quality Standards. Ozone. London: HMSO, 1994.

18 World Health Organisation R, Office for Europe. Update and revision of the air quality guidelines for Europe. Meeting of the working group "classical" air pollutants, Bilthoven, Netherlands, 11-14 October 1994. Copenhagen: WHO, 1995.

19 Harrison RM, Jones $M$. The chemical composition of airborne particles in the UK atmosphere. Sci Total Environ 1995; 168:195-214.

20 Kinney PL, Ware JH, Spengler JD. A critical evaluation of acute ozone epidemiology results. Arch Environ Health 1988:43:168-73.

21 Hoek G, Brunekreef B, Kosterink P, Van den Berg R, Hofschreuder P. Effect of ambient ozone on peak expiratory flow of exercising children in The Netherlands. Arch Environ Health 1993;48:27-32.

22 Devlin RB, McDonnell WF, Mann R, Becker S, House DE, Schreinemachers D, et al. Exposure of humans to ambient levels of ozone for 6.6 hours causes cellular and biochemical changes in the lung. Am 7 Respir Cell Mol Biol 1991;4:72-81.

23 McDonnell WF, Kehrl HR, Abdul-Salaam S, Ives PJ, Folinsbee LJ, Devlin RB, et al. Respiratory response of insbee LJ, Devlin RB, et al. Respiratory response of Environ Health 1991;46:145-50.

24 Department of Health. Advisory Group on the Medical Aspects of Air Pollution Episodes. Third report: Oxides of nitrogen. London: HMSO, 1993.

25 Braun-Fahrlander C, Ackermann-Liebrich U, Schwartz J, Gnehm HP, Rutishauser M, Wanner HU. Air pollution and respiratory symptoms in preschool children. Am Rev Respir Dis 1992;145:42-7.

26 Walters S, Phupinyokul M, Ayres J. Hospital admission rates for asthma and respiratory disease in the West Midlands: their relationship to air pollution levels. Thorax 1995:50: 954

27 Department of Health Committee on the Medical Effects of Air Pollutants. Asthma and outdoor air pollution. London: HMSO, 1995. 